\title{
Interactions between Xwnt-8 and Spemann organizer signaling pathways generate dorsoventral pattern in the embryonic mesoderm of Xenopus
}

\author{
Jan L. Christian ${ }^{1}$ and Randall T. Moon \\ Department of Pharmacology, University of Washington School of Medicine, Seattle, Washington 98195 USA
}

This study analyzes the hierarchy of signals that spatially restrict expression of Xenopus Xwnt-8 to mesodermal cells outside of the Spemann organizer field and examines the potential role that endogenous $X w n t-8$ may play in dorsoventral patterning of the embryonic mesoderm. The effects of ectopic introduction of a Nieuwkoop center-like activity or of ectopic expression of goosecoid, on the distribution of endogenous $X w n t-8$ transcripts were analyzed. The results of these studies are consistent with the hypothesis that maternally derived signals from the Nieuwkoop center function to positively regulate expression of the homeo box gene goosecoid in Spemann organizer cells, leading to a subsequent repression of Xwnt-8 expression in these cells. This exclusion of $X w n t-8$ from cells of the organizer field may be important for normal dorsal development, in that ectopic expression of Xwnt-8 in organizer cells after the midblastula stage, by injection of plasmid DNA, ventralizes the fate of these cells. This is distinct from the previously observed dorsalizing effect of Xwnt-8 when expressed prior to the midblastula stage by injection of RNA. The effects of plasmid-derived Xwnt-8 on isolated blastula animal cap ectoderm were also analyzed. Expression of $X w n t-8$ in animal pole ectoderm after the midblastula stage ventralizes the response of dorsal animal pole cells to activin and allows naive ectodermal cells to differentiate as ventral mesoderm in the absence of added growth factors. Collectively, these data are consistent with the hypothesis that Xwnt-8 plays a role in the mesodermal differentiation of ventral marginal zone cells during normal development. Furthermore, endogenous Xwnt-8 may ventralize the response of lateral mesodermal cells to dorsalizing signals from the organizer, thus contributing to the graded nature of the final body pattern.

[Key Words: Xenopus; Xwnt-8; mesodermal patterning; Spemann organizer]

Received August 14, 1992; revised version accepted November 6, 1992.

In Xenopus, the basic body plan unfolds according to a pattern imprinted on the embryonic mesoderm. Recent years have brought important advances in understanding the early events that guide this process. After fertilization, a reorganization of the egg cytoplasm establishes an inductive activity, the Nieuwkoop center, in dorsal vegetal and marginal zone blastomeres /Gerhart et al. 1989, 1991). This activity is essential for normal anterior and dorsal development, as ablation of the Nieuwkoop center by ultraviolet (UV) irradiation of the egg results in an embryo displaying primarily ventral structures /Gerhart et al. 1989, 1991). Reciprocally, when the Nieuwkoop center is duplicated by transferring dorsal blastomeres (Gimlich and Gerhart 1984; Gimlich 1986; Kageura 1990; Gallagher et al. 1991) or their cytoplasm (Yuge et al. 1990) to the ventral side of a host embryo, a complete

${ }^{1}$ Present address: Oregon Health Sciences University, School of Medicine, Department of Cell Biology and Anatomy, Portland, Oregon 97201 USA. secondary set of dorsal axial structures is formed. In this respect, the activity of the Nieuwkoop center resembles that of the more familiar Spemann organizer. However, these organizing centers differ with regard to the time at which they operate, because the Nieuwkoop center functions during the early blastula stages (Gimlich 1986), whereas the Spemann organizer becomes active at the start of gastrulation (Spemann and Mangold 1924). These organizing centers also differ in that some of the cells that possess Nieuwkoop center activity can induce overlying cells to form dorsal mesodermal structures without directly populating these tissues (Gimlich 1986). In contrast, the Spemann organizer arises from induced cells that will directly populate the most dorsal and anterior mesoderm of the body axis (Smith and Slack 1983; Gimlich and Cooke 1983).

Considerable progress has also been made in understanding how marginal zone cells are induced to form mesoderm, a process that may require signals from endodermal cells of the underlying vegetal hemisphere 
(Nieuwkoop 1969). Specifically, members of the fibroblast growth factor (FGF; Slack et al. 1987; Kimelman et al. 1988; Amaya et al. 1991) and transforming growth factor- $\beta$ (TGF- $\beta$; Asashima et al. 1990, 1991; Smith et al. 1990; Thomasen et al. 1990; van den Eijdnen-van Raaij et al. 1990; Green et al. 1992) families have been implicated as the agents that mediate these signaling events. Less is known about the identity of the agents responsible for the activity of the Nieuwkoop center. Because this activity can be mimicked by injecting mRNA encoding either of two members of the Wnt superfamily, Xwnt-8 and Wnt-1 (Smith and Harland 1991; Sokol et al. 1991; Chakrabarti et al. 1992), or the unrelated maternally expressed protein noggin (Smith and Harland 1992) into embryos, it is possible that $X w n t$ s or noggin are involved in signaling from the Nieuwkoop center, although neither Xwnt-8 nor Xwnt-1 is expressed at the required time or place to contribute normally to this activity (Nordermeer 1989; Christian et al. 1991). Studies in which Xwnt-8 was used as a tool to mimic the Nieuwkoop center activity have led to the proposal that signals from the Nieuwkoop center may modify the response of dorsal marginal zone cells to broadly distributed mesoderm inducing signals, such that these cells differentiate as dorsal rather than ventral mesoderm |Christian et al. 1992; for review, see Kimelman et al. 1992). This dorsal mesoderm then acquires the activity of the Spemann organizer. Several putative transcription factors have been identified that are expressed in the field of the Spemann organizer (Blumberg et al. 1991; Dirksen and Jamrich 1992; Taira et al. 1992) and are considered candidates for initiating its functions. Supporting this possibility, ectopic expression of goosecoid in ventral cells can induce formation of a secondary embryonic axis (Cho et al. 1991).

That studies aimed at unraveling the mysteries of the Spemann organizer have been a primary focus of research in the field of embryonic patterning is not surprising, given the unique signaling properties of these cells. Removal at the gastrula stage of just the small group of cells comprising the organizer converts the embryo from a well-patterned animal, possessing a wide range of mesodermal cell types, to an animal with only the most ventral cell types represented (Stewart and Gerhart 1990). This and other studies (Spemann and Mangold 1924; Slack and Forman 1980; Dale and Slack 1987b) demonstrate that a key function of the organizer is to dorsalize the ventral mesoderm, converting it to a gradient of intermediate forms. The importance of the ventral mesoderm in this process is often overlooked, yet, without it, the organizer would have no substrate on which to act and differentiation would be restricted to dorsal extremes (Kao and Elinson 1988). Ventral development has been described as a default state because ventral mesoderm can form even in the absence of the postfertilization cortical rotation that initiates patterning. However, naive ventral ectoderm will not differentiate as ventral mesoderm in the absence of vegetally derived inducing signals (Nieuwkoop 1969), and it is widely assumed that similar signals are required for mesodermal differentia- tion of ventral marginal zone cells. These primary signals most likely initiate a secondary cascade of zygotic gene activity that ultimately specifies ventral mesodermal fate.

As $X w n t-8$ is a growth factor-inducible putative signaling agent, which is transiently expressed in ventral and lateral mesoderm after the midblastula transition (Christian et al. 1991; Smith and Harland 1992), it is a tenable hypothesis that Xwnt-8 is expressed in response to primary mesoderm-inducing signals and is involved in the secondary steps of ventrolateral mesodermal patterning. To adequately test this hypothesis, blocking the expression or function of endogenous Xwnt-8 in embryos would be required, which is not technically possible at present. The approach that we take in this paper involves ectopic expression of Xwnt-8 by injection of a plasmid expression construct, which allows us to ask how embryonic cells respond to a Xwnt-8 signal that is expressed at the same time as endogenous Xwnt- 8 but in an inappropriate location. This approach is distinct from that of ectopically expressing Xwnt-8 by injection of synthetic RNA, which is translated during the early blastula stage and which leads to the formation of a new Nieuwkoop center (Smith and Harland 1991). In contrast, injected plasmid DNA is not transcribed until after the midblastula transition, at which time the embryo has lost its ability to form, or respond to, a Nieuwkoop center (Gimlich 1986). We report that whereas ectopic expression of $X w n t-8$ from RNA has a dorsalizing effect on embryonic cells (Smith and Harland 1991; Sokol et al. 1991), ectopic expression of Xwnt-8 from a plasmid expression construct has a dramatically different effect both in vivo and in isolated blastula animal cap explants.

\section{Results \\ Xwnt- 8 is expressed in all mesodermal cells except those of the Spemann organizer field}

The localization of Xwnt-8 transcripts in Xenopus embryos was first analyzed by whole-mount in situ hybridization with digoxigenin-labeled riboprobes. Xwnt-8 RNA is first detected in late blastulae (stage 9) in all cells of the marginal zone, with the exception of an arc of cells centered on the dorsal midline (data not shown; Smith and Harland 1991). In early gastrulae (stage 10), expression of $X w n t-8$ persists in ventral and lateral marginal zone cells but is excluded from dorsal equatorial cells within a zone encompassing $\sim 90^{\circ}$ of the embryonic circumference (Fig. 1A; lower embryo), a region defined embryologically as the organizer field (Dale and Slack 1987a; Stewart and Gerhart 1990). Thus, Xwnt-8 is expressed in all marginal zone cells except those within the organizer field, a pattern that persists throughout gastrulation (Fig. 1B). Our results differ somewhat from those of Smith and Harland (1991), who reported that Xwnt-8 expression becomes restricted to ventral cells of the marginal zone during gastrulation. The cause of this discrepancy is not clear but may be attributable to the less extensive protease treatment used in the present studies 

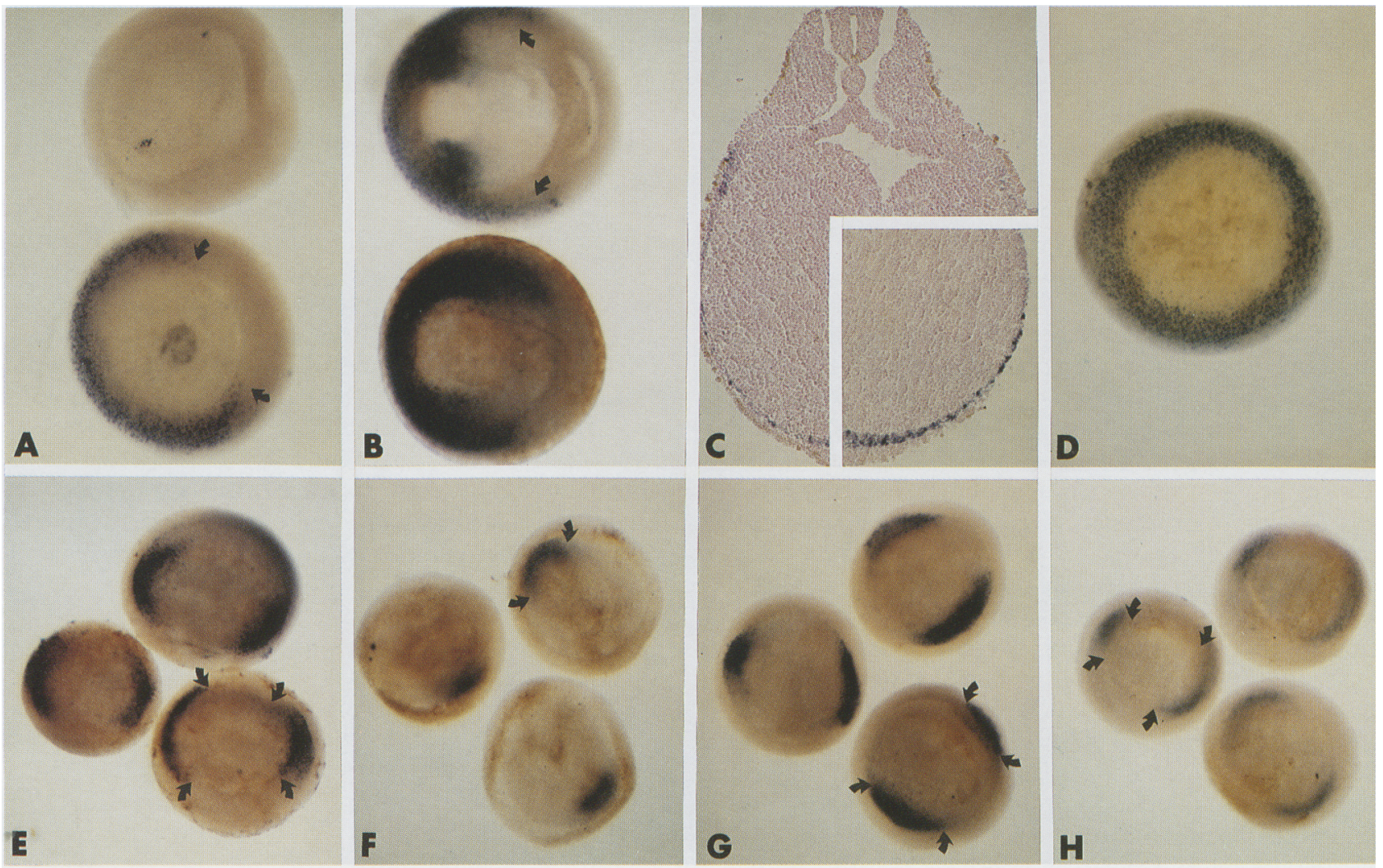

Figure 1. Xwnt-8 is expressed in all mesodermal cells except those of the Spemann organizer field. Whole-mount in situ hybridization studies in Xenopus embryos. (A) Early gastrulae (stage 10) hybridized with Xwnt-8 antisense (lower embryo) and sense (upper embryo) probes. Arrows denote the position of the dorsal lip of the blastopore. $(B)$ Mid-gastrulae (stage 11, lower embryo) and late gastrulae (stage 12, upper embryo). Arrows denote lateral cells that express $X W n t-8$ and are undergoing convergent extension movements toward the animal pole and dorsal midline. $(C)$ Transverse section of a stage-20 neurula showing Xwnt-8 signal in lateral and ventral plate mesoderm. (Inset) Characteristic staining observed when embryos are treated for a longer period with proteinase $\mathrm{K}$ before hybridization. Note that the signal is more intense, but ectodermal surface cells are absent and lateral staining is lost. $(D) X w n t-8$ expression in a UV-irradiated gastrula-stage embryo. $(E-H)$ Early gastrulae (stage 10). Arrows represent the position of dorsal blastopore lips. Illustrated are Xwnt-8 expression in embryos injected ventrally with Wnt-1 $(E)$ or goosecoid RNA $(H)$ during cleavage stages and goosecoid expression in unperturbed $(F)$ and Wnt-1-injected $(G)$ embryos.

(see legend to Fig. 1C; Materials and methods). In midneurula- and late neurula-stage embryos, Xwnt-8 transcripts are enriched in mesodermal cells of the ventral and lateral plate (Fig. 1C) and are also present in posterior mesoderm and in two small regions of the anterior neural plate (data not shown; Smith and Harland 1991). The current findings are consistent with the results of Northern analysis of RNA isolated from various regions of dissected embryos, which demonstrate that Xwnt-8 transcripts are concentrated in the ventral region, rather than in posterior tissues, of mid-neurula- and late neurulastage embryos (Christian et al. 1991).

\section{Signals from the Nieuwkoop center block induction of Xwnt-8 expression in organizer cells}

The observation that $X w n t-8$ transcripts are specifically excluded from cells of the Spemann organizer field raises the question of whether early signaling from the Nieuw- koop center blocks the induction of $X w n t-8$ expression in these cells when zygotic transcription commences at the mid-blastula transition. Consistent with this possibility, obliteration of the Nieuwkoop center by UV irradiation of fertilized eggs results in expression of Xwnt-8 in all cells of the marginal zone (Fig. 1D; Smith and Harland 1991|. Dorsal axial development can be rescued in such UV-ventralized embryos by injection of RNA encoding Xwnt-8 (Smith and Harland 1991; Sokol et al. 1991) or Wnt-1 (Sokol et al. 1991). Rescue is observed even when Xwnt-8 (Smith and Harland 1991) or Wnt-1 (J.L. Christian and R.T. Moon, unpubl.) RNA is introduced into vegetal blastomeres, which do not contribute progeny to the induced dorsal axis. This suggests that these Wnt can mediate the formation of a new Nieuwkoop center (Smith and Harland 1991). To test further the possibility that signals from the Nieuwkoop center may lead to repression of endogenous $X w n t-8$ expression, an ectopic Nieuwkoop center was generated by in- 
jecting Wnt-1 RNA into a ventral vegetal blastomere of cleavage-stage embryos. The distribution of endogenous $X w n t-8$ transcripts was then examined at the early gastrula stage. As shown in Figure 1E, expression of endogenous Xwnt-8 was maintained in the lateral regions of the marginal zone in Wnt-1-injected embryos; but on the ventral side, expression of Xwnt-8 was not detected /Fig. 1E). As a control, we examined the expression of the organizer-specific homeo box gene goosecoid (Fig. 1F; Cho et al. 1991) in embryos injected with Wnt-1 RNA. As expected, because ventral injections of Wnt-1 RNA generate a new Nieuwkoop center, leading to the formation of a new organizer, goosecoid transcripts were found in cells of both the endogenous and ectopic organizer fields of the Wnt-1-injected embryos (Fig. 1G). We conclude that the introduction of Nieuwkoop center-like activity into ventral blastomeres of cleaving embryos leads to ectopic expression of goosecoid, and to repression of $X w n t-8$ expression in ventral marginal zone cells.

These observations raise the possibility that goosecoid may itself be upstream of, and participate in, the negative regulation of Xwnt-8 expression in organizer cells. Consistent with this possibility, during normal development goosecoid RNA is first detected shortly after the mid-blastula transiton, at stage 8.5 (Cho et al. 1991) whereas $X$ wnt -8 transcripts are first detected slightly later, at stage 9 (Christian et al. 1991). To test the hypothesis that expression of goosecoid can lead to the negative regulation of $X w n t-8$, we assayed the effect of ectopically expressed goosecoid on the localization of endogenous Xwnt-8 transcripts. Injection of goosecoid RNA into the ventral marginal zone of four-cell embryos led to the induction of anteriorly truncated secondary dorsal axes in $25 \%$ or $65 \%$ of embryos injected with $\sim 40$ or $400 \mathrm{pg}$ of synthetic RNA, respectively. In this same batch of embryos, a complete loss of Xwnt-8 expression was observed in ventral cells of most gastrula-stage embryos examined (Fig. $1 \mathrm{H}$ ), and a substantial decrease in ventral Xwnt-8 expression was noted in the remaining embryos. As this reduced ventral expression of Xwnt-8 was observed when goosecoid RNA was injected into ventral marginal zone (tier 3 ) blastomeres, but not when RNA was injected into ventral vegetal pole (tier 4) blastomeres of 32-cell embryos (data not shown), goosecoid is not inducing the formation of a new Nieuwkoop center, which, by experimental definition (Smith and Harland 1991) can be formed by injection of these vegetal tier 4 blastomeres.

Recent evidence suggests that signals from the Nieuwkoop center do not directly induce formation of the Spemann organizer but, instead, modify the response of dorsal marginal zone cells to broadly distributed mesoderm-inducing agents (Christian et al. 1992; for review, see Kimelman et al. 1992). As a result, dorsal marginal zone cells differentiate as dorsal mesoderm, which functions as the Spemann organizer. In contrast, ventral marginal zone cells respond to the same inducing agents, in the absence of Nieuwkoop center activity, by forming ventral types of mesoderm. If induction of Xwnt-8 expression is blocked by signals from the Nieuwkoop cen- ter as suggested by the above data, then its expression should be inducible in vitro only in ventral ectodermal cells that have not been exposed to Nieuwkoop center signals. In contrast, expression of goosecoid should be induced only in ectoderm from the dorsal half of embryos, which receive a component of the Nieuwkoop center activity (for review, see Kimelman et al. 1992). To test this possibility, whole animal cap ectoderm, or prospective dorsal or ventral ectoderm regions, were isolated at stage 7-8 and then cultured in the presence of the mesoderm-inducing factor, activin A. As reported previously, expression of both Xwnt-8 (Christian et al. 1991) and goosecoid (Cho et al. 1991) is induced in whole animal cap ectoderm cultured in the presence, but not in the absence, of activin A (Fig. 2). Consistent with our hypothesis, expression of Xwnt-8 is restricted almost exclusively to cells from the prospective ventral half, and goosecoid transcripts are expressed primarily in cells from the dorsal half of the induced animal cap (Fig. 2).

\section{Xwnt- 8 prevents organizer cells from assuming their normal fate}

The presence of Xwnt- 8 transcripts in ventral and lateral marginal zone cells shortly after mesodermal induction raises the possibility that this gene may participate in directing differentiation of the mesoderm along a ventral pathway. Previous attempts to approach this question, by microinjecting synthetic Xwnt-8 RNA into embryos, have shown that early expression of Xwnt-8 mimics the maternal signals of the Nieuwkoop center, leading to induction of secondary dorsal axes /Smith and Harland 1991), an activity that cannot reflect its normal role (Christian et al. 1991, 1992). To circumvent these early effects, we used a DNA expression system to introduce $X w n t-8$ into embryos at an ectopic location, after the

\begin{tabular}{|c|c|}
\hline $\begin{array}{c}\text { Activin } \\
\text { Ectoderm }\end{array}$ & $\begin{array}{llll}+ & + & + & - \\
D & \vee & W & W\end{array}$ \\
\hline Xwnt-8 & \\
\hline goosecoid & $\Leftrightarrow \quad \omega$ \\
\hline$E F-1 \alpha$ & \\
\hline
\end{tabular}

Figure 2. Differential induction of Xwnt-8 and goosecoid expression by activin in ectoderm isolated from prospective dorsal or ventral halves of blastulae. Ectoderm isolated from the prospective dorsal half $(D)$, ventral half $(\mathrm{V})$, or whole $(\mathrm{W})$ animal region of blastulae was cultured in the presence $(+\mid)$ or absence $(-\mid$ of $10 \mathrm{ng} / \mathrm{ml}$ of activin $A$ as indicated above each lane. RNA prepared from 10 explants in each group at control stage 11 was subjected to Northern blot analysis. The filter was successively hybridized to Xwnt-8 and goosecoid riboprobes, as indicated at left, and then to an EF-1 $\alpha$ cDNA probe to determine equivalence of loading. 
time that the Nieuwkoop center is functional. A plasmid construct (CSKA-X8) was prepared by cloning a Xwnt-8 cDNA downstream of the Xenopus borealis cytoskeletal actin promoter. This promoter has been shown to be active following injection into Xenopus embryos but not until after the mid-blastula stage (Harland and Misher 1988). A control construct (CSKA-CAT) was generated by cloning the coding region of the bacterial chloramphenicol acetyltransferase (CAT) gene downstream of the same promoter.

To direct the plasmid to cells of the organizer field, DNA was injected into two blastomeres of four-cell embryos near the equator at the dorsal midline. Northern analysis of RNA extracted from uninjected or injected embryos at various stages of development revealed that overexpression of Xwnt-8 in embryos harboring the CSKA-X8 plasmid begins shortly after the mid-blastula transition, peaks during the gastrula stages, and declines rapidly during neurulation, analogous to the temporal pattern of expression of endogenous Xwnt-8 (Fig. 3A). The expression of CAT transcripts from injected plasmid is detectable by stages $8-9$, peaks during the neurula stages, and persists at least through the tailbud stage of development (Fig. 3A). The spatial distribution of $X w n t-8$ transcripts in CSKA/X8-injected embryos was assayed by Northern blot analysis of RNA isolated from various regions of embryos (Fig. 3B). Whereas endogenous $X w n t-8$ transcripts are confined primarily to ventral regions of uninjected (Christian et al. 1991) or CSKA/CAT-injected embryos (Fig. 3B; more readily visible on longer exposures), $X w n t-8$ RNA is greatly overexpressed in dorsal cells of gastrula-stage (Fig. 3B, cf. lane 1 with lane 4) and neurula-stage (Fig. 3B, cf. lane 7 with lane 11) embryos injected with CSKA-X8.

To determine whether Xwnt-8 transcripts from injected plasmids were expressed primarily in organizer cells during gastrulation, and in descendents of these cells at later stages, we performed in situ hybridization with CSKA/X8-injected embryos. In the majority of early gastrula-stage embryos that were examined, Xwnt-8 transcripts were observed in most or all cells of the dorsal blastopore lip (Fig. 3C), where the endogenous gene is not normally expressed (Fig. 1). By the late neurula stage, the extent of expression of Xwnt-8 from the injected plasmid was more variable between individual embryos, and the pattern of expression was more mosaic (data not shown). To determine whether the observed $X w n t-8$ signal was attributable to hybridization of the probe to Xwnt- 8 transcripts generated by the plasmid or to hybridization with the plasmid itself, some CSKA/ $\mathrm{X} 8$-injected embryos were pretreated with sodium hydroxide to hydrolyze cellular RNA. This led to a complete loss of signal (data not shown). Importantly, as described later, immunological localization of epitopetagged Xwnt-8 demonstrates that Xwnt-8 protein from injected plasmids is expressed in the field of the Spemann organizer.

Having investigated the expression of Xwnt- 8 from the injected plasmids, we turned to an analysis of the phenotypes of the injected embryos. In embryos injected
A

\begin{tabular}{|c|c|c|c|}
\hline & CSKA-CAT & CONTROL & CSKA-X8 \\
\hline$N / F$ stage & $\begin{array}{lllll}3 & 9 & 11 & 21 & 32 \\
\end{array}$ & $\begin{array}{lllll}3 & 9 & 11 & 21 & 32 \\
\end{array}$ & $\begin{array}{lllll}3 & 9 & 11 & 21 & 32 \\
\end{array}$ \\
\hline Xwnt-8 & - & - & \\
\hline CAT & $6=$ & & \\
\hline$E F-1 \alpha$ & & & \\
\hline
\end{tabular}

B
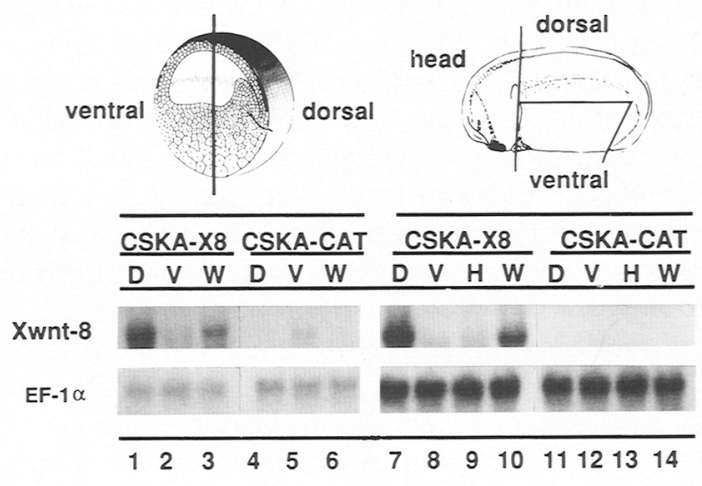

C

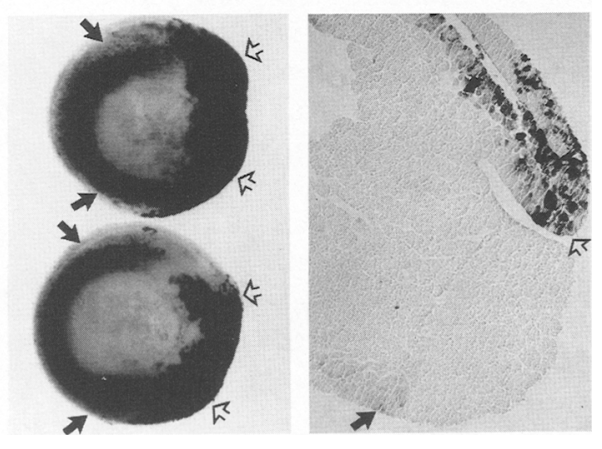

Figure 3. Expression of Xwnt-8 and CAT transcripts following injection of CSKA-X8 or CSKA-CAT DNA into Xenopus embryos. (A) RNA was isolated from injected or uninjected embryos at cleavage (stage 3), blastula (stage 9), gastrula (stage 11), neurula (stage 21), or tailbud (stage 32) stages, as indicated at the top of $A[(\mathrm{~N} / \mathrm{F})$ Nieuwkoop and Faber 1967] and subjected to gel blot analysis. The filter was successively hybridized with the probes indicated at left. (B) Gastrulae (stage 10; lanes 1-6) or neurulae (stage 21 ; lanes $7-14$ ) were dissected as illustrated. Northern blots containing RNA from the region indicated above each lane were successively hybridized with the probes indicated at left. The filter was exposed to film for $10 \mathrm{hr}$, or for $6 \mathrm{hr}$, to obtain the Xwnt-8 signals shown for lanes 7-14, and $1-6$, respectively. (D) Dorsal; (V) ventral; (W) whole; (H) head. (C) Whole-mount in situ hybridization of Xwnt-8 probes to stage-11 gastrulae that had received dorsal injections of CSKA$\mathrm{X} 8$. Solid arrows denote signal from endogenous $X w n t-8$ transcripts in ventrolateral maginal zone cells; open arrows indicate staining of dorsal lip cells from plasmid-derived Xwnt-8. $(A \mid$ Whole gastrulae; $(B)$ sagittal section through a representative embryo.

with either CSKA-X8 or CSKA-CAT, gastrulation was initiated on the dorsal side of the embryo, and expression 
of goosecoid was apparently normal (Fig. 4A,B). By the mid-neurula stage, however, a highly reproducible loss of anterior structures was observed in CSKA/X8-injected embryos. This phenotype was more apparent by the tailbud stage (Fig. 4D) and was dramatically obvious by the tadpole stage (Fig. 4F). Specifically, we found that CSKA/ $\mathrm{X} 8$-injected embryos completely lacked eyes and cement gland or were severely microcephalic (Table 1). Embryos that developed following dorsal injections of CSKACAT (Fig. 4C,E; Table 1), or ventral marginal zone injections of CSKA-X8 (Table 1) did not exhibit specific phenotypic defects. Because ectopic expression of goosecoid in ventral cells following plasmid injection can induce the formation of secondary axes $(H$. Steinbesser and $E$. DeRobertis, pers. comm.), the inability of plasmid-derived $X w n t-8$ to do so is not an artifact that results from mosaicism or other problems typical of plasmid expression systems.

Because the ectopically expressed $X w n t-8$ was directed by the choice of injection site primarily to mesodermal cells, and not to the ectodermal cells which give rise to anterior neural structures, it was possible that the observed head defects were incurred indirectly as a result of the effect of $X w n t-8$ on the anterior dorsal mesoderm. To test this possibility, CSKA-X8 was injected into specific dorsal blastomeres of 32-cell embryos to direct expression of Xwnt-8 to particular tissues. The 32-cell embryo is arranged as four tiers of eight cells (tiers 1-4, from animal pole to vegetal pole), with forebrain originating primarily from dorsal tier 1 blastomeres; extreme dorsal

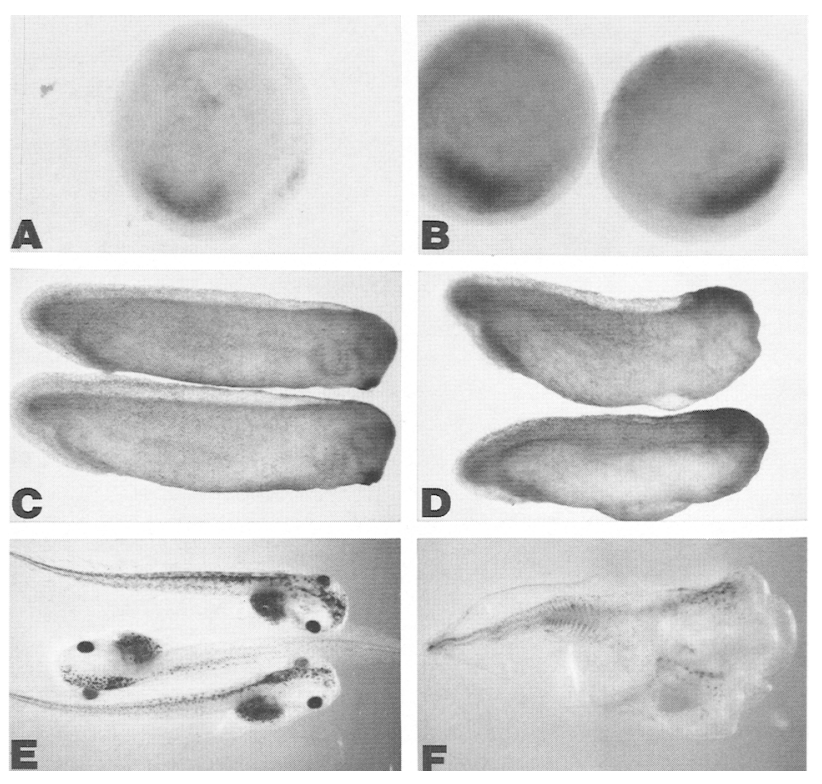

Figure 4. Deletion of anterior structures following dorsal injection of CSKA-X8 into Xenopus embryos. CSKA-CAT $(A, C, E)$ or CSKA-X8 $(B, D, F)$ DNA was injected as described in the text. $(A, B)$ Whole-mount in situ hybridization of goosecoid probes to early gastrulae (stage $101 / 2) .(C-F)$ Photographs of embryos fixed at the tailbud (stage $34, C, D$ ) or tadpole (stage 45 , $E, F)$ stage.
Table 1. Head defects produced by ectopic expression of Xwnt- 8 in post-mid-blastula stage Xenopus embryos

\begin{tabular}{lccrrrr}
\hline & \multirow{2}{*}{$\begin{array}{l}\text { Stage } \\
\text { (cells) }\end{array}$} & $\begin{array}{l}\text { Injection } \\
\text { sNite }\end{array}$ & \multicolumn{4}{c}{ External phenotype } \\
\cline { 3 - 7 } & wt & aceph & micro & $N$ \\
\hline CSKA-X8 & 4 & DMZ & 3 & 81 & 16 & 276 \\
CSKA-CAT & 4 & DMZ & 100 & 0 & 0 & 183 \\
CSKA-X8 & 4 & VMZ & 87 & 3 & 10 & 67 \\
CSKA-X8 & 32 & tier 1 & 75 & 2 & 22 & 49 \\
& & tier 2 & 42 & 10 & 48 & 52 \\
& & tier 3 & 9 & 40 & 51 & 47 \\
& & tier 4 & 90 & 0 & 10 & 29 \\
\hline
\end{tabular}

DNA was injected into the marginal zone region of two blastomeres of 4-cell embryos, near the prospective dorsal (DMZ) or ventral (VMZ) midline, or into two dorsal midline blastomeres residing in tier $1,2,3$, or 4 of 32 -cell embryos as indicated. Embryos surviving until stage 40 were scored as follows: Wild type (wt), showing no specific defects; acephalic (aceph), lacking any visible retinal pigment; microcephalic (micro), reduced head, but with some visible retinal pigment. Numbers are expressed as percentages except for $N$, which denotes sample size.

mesoderm, including notochord and head mesoderm, arising predominantly from dorsal tiers 2 and 3, respectively; and tier 4 cells contributing mainly to the endoderm (Dale and Slack 1987). If the anterior defects observed following ectopic expression of Xwnt-8 were attributable to a direct effect on the neural ectoderm, then injection of CSKA-X8 into dorsal tier 1 cells should produce anterior truncations more frequently than injections into dorsal tier 2 or tier 3 cells. However, one would not expect a perfect correlation between the injection site and the phenotype because of variation between the fate of blastomeres in different embryos (Dale and Slack 1987), and because Wnt proteins, being secreted (Bradley and Brown 1990; Papkoff and Schryver 19901, may influence the differentiation of descendents of noninjected cells. Nevertheless, we observed a clear trend in the phenotypes of injected embryos. Specifically, anterior deletions were common when Xwnt-8 was directed to cells destined to give rise to anterodorsal mesoderm (Table 1), particularly when the plasmid was directed to cells that would differentiate as head mesoderm (tier 3 injection), but anterior defects were infrequent following tier 1 injections. We conclude that the anterior truncations observed following ectopic expression of Xwnt-8 most likely represent primary defects in the anterior dorsal mesoderm, rather than direct effects on the neural ectoderm.

Histological analysis of injected embryos revealed that the anterior extent of neural development in most Xwnt8-expressing tadpoles was limited to the level of midbrain or hindbrain (Fig. 5D,H; Table 2). In contrast, normal anterior structures, including eyes and forebrain, were observed in all CAT-expressing tadpoles that were examined (Fig. 5A,G; Table 2). In addition to anterior defects, the notochord was either absent (Fig. 5E,F,H; Table 2) or present but aberrantly located ventral to the 


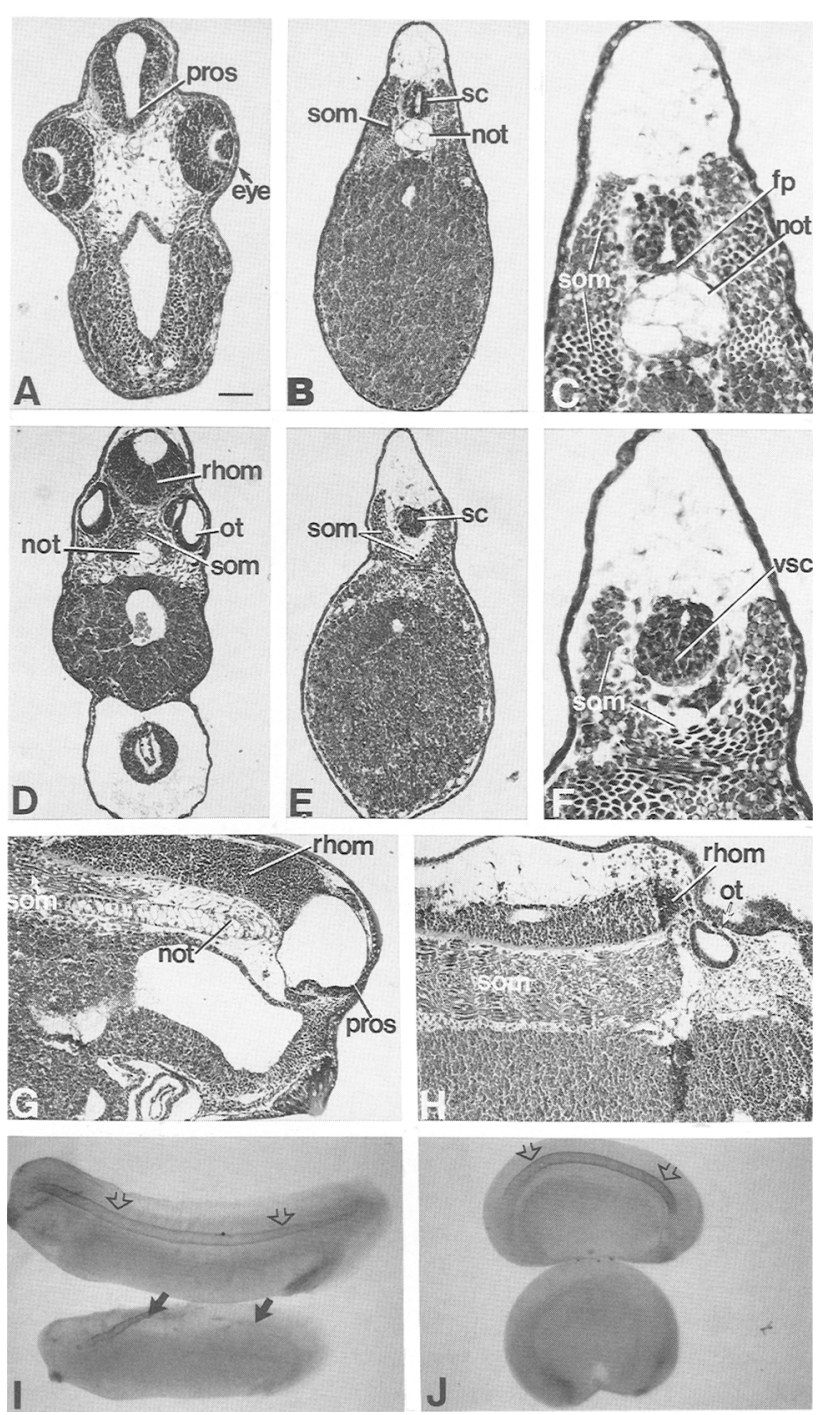

Figure 5. Injection of CSKA-X8 DNA into dorsal blastomeres of Xenopus embryos results in loss of forebrain and notochord. $(A-F)$ Transverse sections taken at a comparable distance from the anterior end of CSKA/CAT $(A-C)$ - or CSKA/X8 $(D-F)$-injected embryos. $(G, H)$ Sagittal sections through CSKA/CAT $(G)$ - or CSKA/X8 $(H)$-injected embryos. Abbreviations are as follows: (pros) Prosencephalon (forebrain); (som) somitic mesoderm (muscle); (not) notochord; (sc) spinal cord; (fp) floor plate cells of the ventral spinal cord; (rhom) rhombencephalon (hindbrain); (ot) otic vessicle (ear anlage); (vsc) ventral wall of the spinal cord. Bar in $A$ represents $400 \mu \mathrm{m}$ in all panels except for $C$ and $F$, where it represents $150 \mu \mathrm{m}$. $(I, I)$ Notochord immunostaining in stage $28(I)$ or stage $21(/)$ neurulae using monoclonal antiserum Tor70. Open arrows denote normal notochord staining in CSKA/CAT-injected (upper) embryos; solid arrows in $I$ indicate anterior and (faint) posterior notochord staining of this CSKA/X8-injected embryo. Staining is not detected between the two arrows in the mid-body region. The lower embryo in $I$ represents a CSKA/X8-injected embryo in which notochord staining is absent.

somitic tissue in $89 \%$ of CSKA/X8-injected embryos that were analyzed (Fig. 5D; Table 2). These embryos exhibited morphological abnormalities of the neural tube in that floor plate cells were absent, as evidenced by a broadening of the ventral wall of the spinal cord (Fig. $5 \mathrm{~F}$, vsc). In addition, the somite files on either side of the cord were fused with each other along the ventral midline (Fig. 5F). These defects have been reported previously in notochordless Xenopus embryos generated by low-level UV irradiation (Youn and Malacinski 1981; Clarke et al. 1991). All CAT-expressing tadpoles possessed a normal notochord, directly underlying a morphologically normal neural tube, and somitic tissue was confined to lateral regions (Fig. 5B,C,G; Table 2).

Embryos were also assayed for the presence or absence of notochord by whole-mount immunocytochemical staining using the monoclonal antiserum Tor70 (Kushner 1984; Bolce et al. 1992।. Of the 55 CSKA/X8-injected embryos that were examined, $73 \%$ lacked any detectable notochord staining, as illustrated in Fig. 5J (lower embryo); $18 \%$ showed rare isolated patches of immunoreactive notochord cells (data not shown) or partial notochords, which did not extend the full length of the body axis (Fig. 5I, lower embryo); and 9\% demonstrated an apparently normal notochord. In contrast, all CSKA/ CAT-injected embryos showed normal notochord staining (Fig. 5I,J, upper embryos). To investigate the possibility that embryos expressing Xwnt-8 in dorsal cells initially formed a normal notochord that later regressed, embryos were examined at the early neurula stage, shortly after the time that differentiation of notochord tissue is first evident histologically. Notochords were present in all CSKA/CAT-injected neurulae but were not detected in $80 \%$ of CSKA/X8-injected embryos of the same age $(n=10)$. In the latter embryos, the presumptive notochordal region was occupied by somitic mesoderm, which gives rise to skeletal muscle. Taken together, these data suggest that misexpression of $X w n t-8$ in cells of the organizer field, during the time when endogenous $X w n t-8$ is expressed in ventrolateral cells, blocks the normal differentiation of dorsal marginal zone cells as head mesoderm and notochord.

\section{Xwnt- 8 can ventralize the fate of prospective notochord cells}

A c-myc-epitope-tagged derivative of Xwnt-8, termed $X w n t-8^{\text {myc }}$, was generated and cloned downstream of the cytoskeletal actin promoter to enable us to test whether the injected plasmids led to synthesis of Xwnt-8 polypeptides in the organizer field and to enable us to trace the fate of $X w n t-8$-expressing cells. The plasmid construct $\left(\mathrm{CSKA}-\mathrm{X} 8^{\mathrm{myc}}\right)$ was injected into the dorsal marginal zone of four-cell embryos, and Xwnt- $8^{\text {myc }}$ expressing cells were identified by whole-mount immunocytochemical analysis. At the onset of gastrulation (stage 10), myc staining was observed in $80-90 \%$ of dorsal marginal zone cells in the majority of embryos that were examined (Fig. 6A,B). By the mid-neurula stage, the pattern of expression of $X w n t-8^{\text {myc }}$ had become more mosaic, as has been observed for other proteins expressed in Xeno- 
Table 2. Ectopic expression of Xwnt-8 in dorsal mesodermal cells inhibits differentiation of forebrain and notochord

\begin{tabular}{lrrrrrrrr}
\hline & \multicolumn{3}{c}{ Anterior extent of neural tissue } & & \multicolumn{3}{c}{ Notochord } \\
\cline { 2 - 4 } DNA & fore & mid/hind & SC & & present & absent & abnormal & $N$ \\
\hline CSKA-X8 & 6 & 83 & 11 & 11 & 72 & 17 & 36 \\
CSKA-CAT & 100 & 0 & 0 & 100 & 0 & 0 & 37 \\
\hline
\end{tabular}

DNA was injected near the dorsal midline in the equatorial region of two blastomeres of four-cell embryos. Survivors were analyzed histologically at stage 34 or 40. Abbreviations: (Fore) Forebrain; (mid/hind) midbrain/hindbrain; (SC) spinal cord; (present) notochord present, normal appearance and placement; (absent) no notochord cells detected; (abnormal) some notochord cells detected but abnormal placement, as described in text. Numbers are expressed as percentages except for $N$, which denotes sample size.

pus embryos following injection of DNA constructs (Vize et al. 1991). In 8 of 11 CSKA/X8 ${ }^{\text {myc }}$ injected neurulae which were analyzed histologically, myc staining was observed in a fraction of the cells directly underlying the neural tube (Fig. 6C). The position of these Xwnt$8^{\mathrm{myc}}$-expressing cells is consistent with that predicted by fate-mapping studies for cells derived from the dorsal marginal zone (Dale and Slack 1987a). However, these cells have differentiated with a more ventral fate than that predicted, that is, as muscle rather than notochord. The observation that peak expression of plasmid-derived $X$ wnt -8 occurs during gastrulation (Fig. 3A) may account for the fact that $X w n t-8^{\mathrm{myc}}$ is not present in all affected cells of neurulae. In the remaining three neurula-stage embryos that were analyzed, the notochord was present and lacked detectable myc staining. These data support the hypothesis that expression of Xwnt-8 after the midblastula transition, in prospective notochord cells, diverts the fate of these cells along a more ventral pathway.

To test whether ectopic expression of Xwnt-8 after mid-blastula stage can also ventralize the fate of prospective muscle cells, CSKA-X $8^{\text {myc }}$ was injected into the lateral marginal zone of four-cell embryos, thereby di- recting expression to cells fated to give rise to somites (Dale and Slack 1987a). Because these same cells normally express endogenous $X w n t-8$, this experiment tests the possibility that supraphysiological levels of Xwnt-8 generated by plasmid injection can alter the fate of any cells. At the early gastrula stage, myc staining was observed in $80-90 \%$ of cells in the lateral marginal zone of injected embryos (data not shown), but by the neurulastage the degree of mosaicism had increased, analogous to that observed following dorsal injections. In all neurula-stage embryos examined histologically $(n=5)$, the expression of $X W n t-8^{\mathrm{myc}}$ in somitic mesoderm did not affect the differentiation of these cells as skeletal muscle (Fig. 6D).

\section{Xwnt- 8 is sufficient for ventral mesodermal differentiation of isolated ectoderm}

The results presented above suggest that ectopically expressed Xwnt- 8 can ventralize the fate of prospective dorsal mesodermal cells. We therefore used an in vitro assay to test whether Xwnt-8 might be involved more directly in ventral mesodermal differentiation. CSKA$\mathrm{X} 8$ was injected into the animal hemisphere of two dor-
Figure 6. Lineage analysis of Xwnt- $8^{\text {myc }}$ expressing cells. CSKA-X $8^{\text {myc }}$ was injected into the dorsal $(A-C)$ or lateral $(D)$ marginal zone of four-cell embryos, and expression of $X w n t-8^{\text {myc }}$ protein was detected by wholemount immunocytochemical staining with monoclonal antiserum 9E10. $(A \mid$ Whole gastrulae (stage 10). $(B)$ Sagittal section through a representative stage-10 embryo; dorsal lip indicated by open arrow. $(C-D)$ Transverse sections through neurulae (stage 21). Abbreviations are as in Fig. 5. Curved arrows in $A$ denote dorsal marginal zone staining and, in other panels, denote representative $X w n t$ $8^{\text {myc }}$-expressing cells.
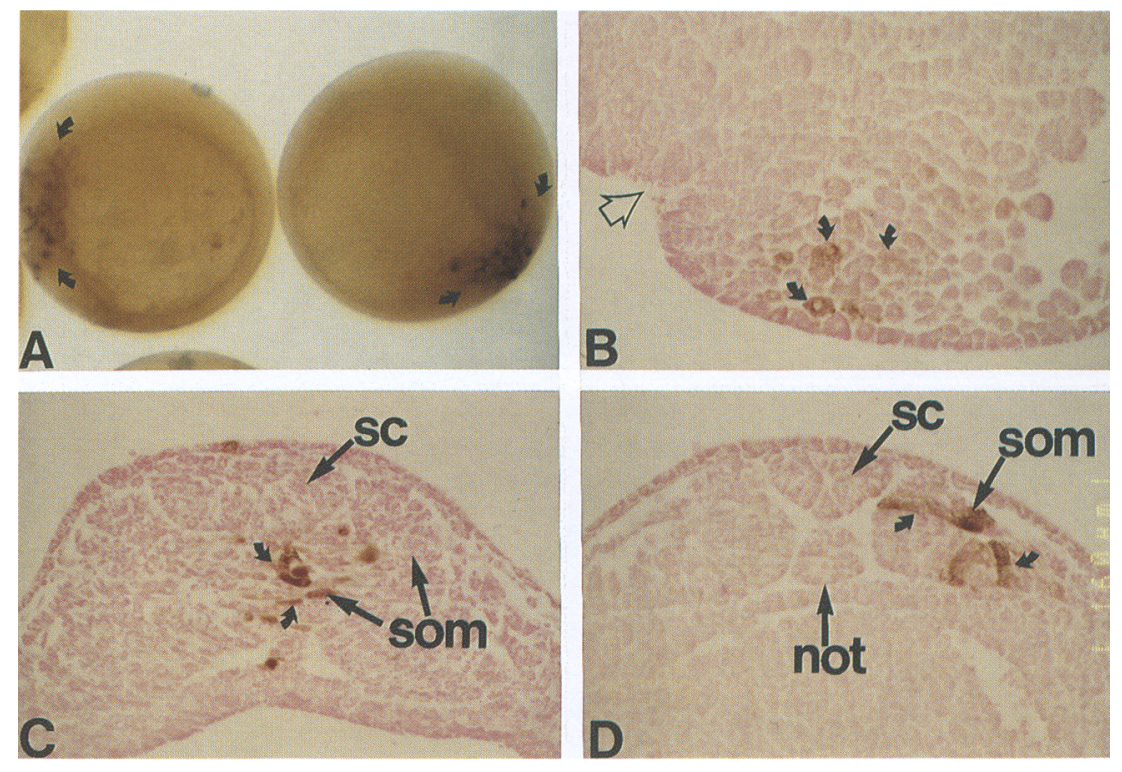
sal or ventral blastomeres of four-cell embryos. Injected and uninjected control embryos were cultured until stage 8 , at which time the upper two-thirds of the animal cap was excised and cultured until control stage 40 . Ectoderm isolated from uninjected embryos differentiated as spheres of atypical epidermis (Fig. 7A,D; Table 3). In contrast, ectoderm isolated from embryos that had received ventral injections of CSKA-X8 formed vesicular structures (Fig. 7B). These explants contained cell types histologically classified as being representative of ventral mesodermal inductions (Green et al. 1990), including mesenchyme, mesothelium, and loose cells that resemble immature erythrocytes (Fig. 7E; Table 3). When this same assay was repeated using smaller explants, which consisted of approximately the upper one-third of the animal cap, a similar result was seen. Ectoderm iso-

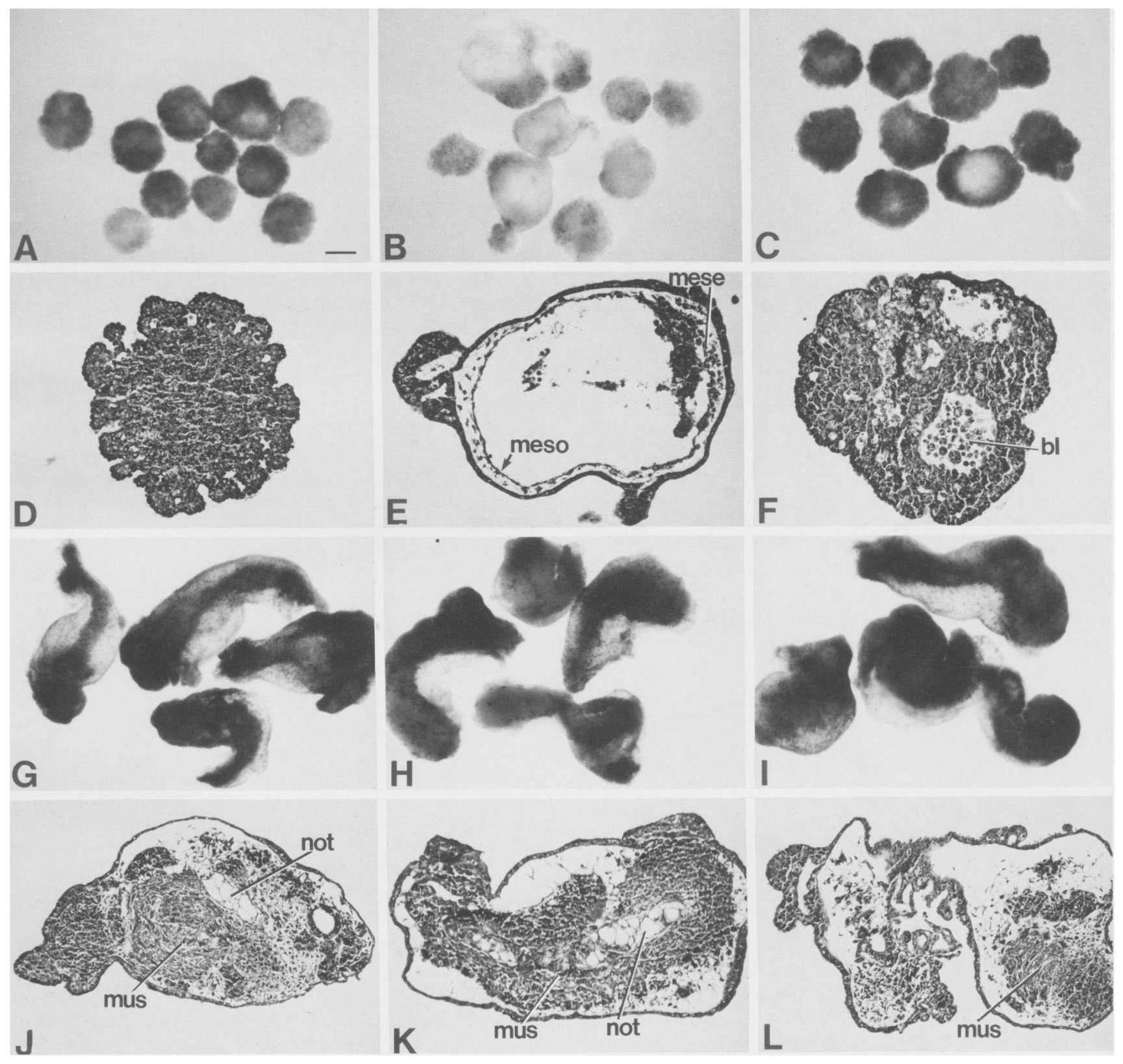

Figure 7. Expression of $X w n t-8$ after the midblastula transition induces ventral mesoderm and inhibits induction of notochord by activin in ectodermal explants. Ectoderm was isolated from blastulae that had received no injection $(A, D, G, J)$, ventral injections $(B, E, H, K)$, or dorsal injections $(C, F, I, L)$ of CSKA-X8. Photographs of intact explants $(A-C, G-I)$ or histological sections $(D-F, J-L)$ of explants cultured in the absence $(A-F)$ or presence $(G-L)$ of $10 \mathrm{ng} / \mathrm{ml}$ of activin A until control stage 40 are shown. Abbreviations are as follows: (mese) Mesenchyme; (meso) mesothelium; (bl) cells resembling blood cells; (mus) muscle; (not) notochord. Bar in $A, 1$ mm $(A-C), 310 \mu \mathrm{m}(D-F), 620 \mu \mathrm{m}(G-I)$, or $400 \mu \mathrm{m}(J-L)$. 
Table 3. Inductive effects of Xwnt-8 and activin on Xenopus blastula ectoderm

\begin{tabular}{|c|c|c|c|c|c|c|c|}
\hline \multirow{2}{*}{$\begin{array}{l}\text { Blastomeres } \\
\text { injected }\end{array}$} & \multirow{2}{*}{$\begin{array}{l}\text { Activin A } \\
(\mathrm{ng} / \mathrm{ml})\end{array}$} & \multicolumn{5}{|c|}{ Tissues induced at stage 40} & \multirow[b]{2}{*}{$N$} \\
\hline & & epi & eryth & mes & mus & not & \\
\hline None & 0 & 91 & 7 & 4 & 0 & 0 & 45 \\
\hline Dorsal & 0 & 46 & 46 & 11 & 0 & 0 & 28 \\
\hline Ventral & 0 & 6 & 56 & 67 & 0 & 0 & 36 \\
\hline None & 4 & 0 & - & - & 100 & 27 & 11 \\
\hline Dorsal & 4 & 0 & - & - & 100 & 0 & 8 \\
\hline Ventral & 4 & 0 & - & - & 100 & 20 & 10 \\
\hline None & 10 & 0 & - & - & 100 & 60 & 20 \\
\hline Dorsal & 10 & 0 & - & - & 100 & 0 & 13 \\
\hline Ventral & 10 & 0 & - & - & 100 & 71 & 14 \\
\hline None & 40 & 0 & - & - & 100 & 67 & 15 \\
\hline Dorsal & 40 & 0 & - & - & 100 & 5 & 21 \\
\hline Ventral & 40 & 0 & - & - & 100 & 35 & 20 \\
\hline
\end{tabular}

CSKA-X8 DNA was injected into the animal hemisphere of two dorsal or ventral blastomeres of four-cell embryos. Animal caps excised from injected or uninjected embryos were cultured in the absence or presence of activin $A$ at the indicated concentrations. Explants were analyzed histologically at control stage 40. (epi) Atypical epidermis; (eryth) cells resembling immature erythrocytes; (mes) mesenchyme and mesothelium; (mus) muscle; (not) notochord; (-) not examined. Numbers are expressed as percentages except for $N$, which denotes sample size.

lated from embryos injected with Xwnt-8 RNA, to provide $X w n t-8$ before the mid-blastula transition, differentiated as atypical epidermis in $93 \%$ of cases examined $(n=14)$, whereas $74 \%$ of explants isolated from CSKA/ $\mathrm{X} 8$-injected embryos contained erythroid-resembling cells, $26 \%$ contained mesenchyme or mesothelium, and $5 \%$ differentiated as atypical epidermis $(n=19)$. Explants from dorsally injected embryos also showed autonomous differentiation of ventral mesoderm (Fig. $7 \mathrm{C}, \mathrm{F})$, but these inductions were less frequent and less extensive than those observed in explants expressing $X w n t-8$ in ventral cells (Table 3 ). These results demonstrate that expression of Xwnt-8 in ectodermal cells after the mid-blastula transition is sufficient to cause these cells to differentiate as ventral mesoderm in the absence of exogenously added mesoderm-inducing factors.

\section{Xwnt- 8 ventralizes the response of dorsal ectoderm to activin}

Prospective dorsal and ventral regions of Xenopus blastula animal cap tissue respond differently to identical concentrations of the mesoderm-inducing factor activin A. Specifically, the dorsal halves of ectodermal explants differentiate into anterodorsal structures, including notochord and forebrain, whereas ventral or UV-ventralized ectoderm form muscle, but not notochord (Sokol and Melton 1991; Bolce et al. 1992), and hindbrain, but not forebrain (Bolce et al. 1992), in response to activin. Because endogenous $X w n t-8$ is expressed in ventral, but not dorsal, halves of animal caps in response to activin
(Fig. 2), it is possible that it plays a role in the observed differences in the differentiation of dorsal versus ventral activin-treated caps. As it is not yet possible to block the expression or function of endogenous $X w n t-8$ to test this hypothesis, we instead injected CSKA-X8 into the animal hemisphere of two dorsal or ventral blastomeres of four-cell embryos, to overexpress Xwnt-8 on the ventral side, where it is normally expressed in response to activin, or on the dorsal side, where it is not expressed in response to activin. The upper two-thirds of the animal caps were excised at stage 8 , and explants were cultured in the presence of activin A until control stage 40. In the presence of activin, ectoderm isolated from embryos injected ventrally (Fig. 7H) or dorsally (Fig. 7I) with CSKA$\mathrm{X} 8$ elongated and superficially resembled explants isolated from uninjected controls (Fig. 7G). Histological analysis of explants revealed that doses of activin that induced extensive notochord formation in ectoderm from uninjected embryos (Fig. 7J) induced notochord at a similar frequency in ectoderm isolated from embryos re-

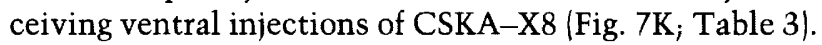
In contrast, ectoderm from embryos in which CSKA-X8 was directed to dorsal cells formed muscle in response to activin (Fig. $7 \mathrm{~L}$ ), but notochord was rarely observed (Table 3). All activin-treated animal caps appeared to contain neural tissue, the presence of which was verified by probing Northern blots of RNA isolated from explants with the neural-specific marker, XIF3 (Sharpe et al. 1989|. XIF3 transcripts were detected at fairly equivalent levels in activin-treated explants of uninjected, ventrally injected, or dorsally injected embryos (data not shown). We conclude that Xwnt-8 can inhibit dorsal ectodermal cells from differentiating as notochord in response to signals initiated by activin.

\section{Discussion}

In Xenopus embryos the Xwnt-8 gene is first expressed shortly after the mid-blastula stage, and transcripts are present in all marginal zone cells except for those of the Spemann organizer field. We have found that when a second Spemann organizer is generated on the ventral side of the embryo by injection of Wnt-1 mRNA, which mimics the early Nieuwkoop center signals, or by injection of goosecoid mRNA, which initiates a later cascade of events leading to creation of a Spemann organizer, $X w n t-8$ transcripts are absent from cells of both the endogenous and the artificially induced organizer fields. These results suggest that signals from the Nieuwkoop center function to positively regulate expression of goosecoid in cells of the Spemann organizer field, which subsequently leads to the repression of Xwnt-8 expression. These data do not bear on whether goosecoid directly represses expression of Xwnt-8, or whether there are intermediates between goosecoid and the negative regulation of Xwnt-8.

Furthermore, our results suggest that this repression of $X w n t-8$ expression in Spemann organizer cells is important for normal dorsal development. We have observed that when Xwnt-8 is ectopically expressed in cells of the 
organizer field, the notochord and the forebrain fail to differentiate. Although this phenotype resembles that produced by decreasing the amount of organizer present in the embryo, (Youn and Malacinski 1981; Stewart and Gerhart 1990; Clarke et al. 1991), it is unlikely that the same mechanism accounts for the Xwnt-8-induced phenotype. Whereas quantitative decreases in the organizer always lead to serial deletions of dorsal structures from the anterior end (Stewart and Gerhart 1990), some CSKA/X8-injected embryos possessed portions of the anterior, but not the posterior, notochord (e.g., Fig. 5I, lower embryo). In addition, the formation of a functional organizer is apparent in CSKA/X8-injected embryos in that expression of goosecoid, a molecular marker of the organizer, is maintained, and nervous tissue and muscle are always present. In contrast, when the organizer is absent, goosecoid transcripts are not detected (Cho et al. 1991) and embryos lack all dorsal axial structures, including muscle and spinal cord (Gerhart et al. 1991).

Another mechanism by which ectopically expressed $X w n t-8$ might produce the observed phenotype is by decreasing the responsiveness of Xwnt-8-expressing organizer cells to endogenous dorsalizing signals, thereby blocking the normal differentiation of these cells, as notochord and head mesoderm. According to this hypothesis, the specific deletion of forebrain, but not hindbrain, in CSKA/X8-injected embryos would be attributable to defects in, and the subsequent loss of patterning signals from, the head mesoderm. In support of this proposal, most embryos develop normally when $X w n t-8$ is targeted to neurectoderm, from which the forebrain develops (Table 1, tier 1 injections), but not when it is targeted to prospective head mesoderm (Table 1, tier 3 injections). Furthermore, patterning signals from the head mesoderm have been shown to be required for the regional differentiation of the eyes and forebrain, but not for the differentiation of the hindbrain (Adelmann 1934; for review, see Holtfreter and Hamburger 1955). Taken together, our data are most consistent with the hypothesis that ectopic expression of Xwnt-8 in cells of the Spemann organizer does not affect the dorsalizing signals normally emitted by these cells but does attenuate the competence of the same cells to respond to such signals. As a result, the fate of organizer cells is altered, in that head mesoderm is defective or lacking and presumptive notochord differentiates with a more ventral fate, as muscle. We hypothesize that endogenous Xwnt-8 may play a similar role in attenuating the response of lateral marginal zone cells to dorsalizing signals from the organizer, so that these $X w n t-8$-expressing cells differentiate with a fate more ventral than that of non-Xwnt-8-expressing dorsal marginal zone cells. Importantly, because most of the embryonic muscle is derived from Xwnt-8expressing ventrolateral marginal zone cells (Keller 1976), our observation that ectopically expressed Xwnt-8 cannot ventralize the fate of these cells is consistent with this hypothesis.

Several alternative interpretations of our data are possible. First, it is possible that rather than differentiating with a more ventral fate, Xwnt-8-expressing dorsal mid- line cells have died, allowing muscle tissue to migrate into the position normally occupied by these cells. This seems unlikely given the results of lineage analysis studies, which suggest that descendents of $X w n t-8^{\text {myc }}$-expressing prospective notochord cells do survive at least until the mid-neurula stage, at which time they have begun to differentiate as muscle. It is also possible that the loss of notochord is an artifact caused by the supraphysiological levels of Xwnt-8 generated by plasmid injection. Inconsistent with this interpretation, however, is the observation that the same massive overexpression of $X w n t-8$ in cells that normally express this gene product, that is, ventral (Table 1) or lateral (Fig. 6D) marginal zone cells, has no effect on cell fate. Furthermore, several pieces of circumstantial evidence exist that suggest that physiological levels of Xwnt-8 may prevent cells from forming notochord or head mesoderm, as discussed below.

Embryological evidence supports the hypothesis that signals that attenuate the response of prospective mesodermal cells to dorsalizing signals may operate in vivo. First, ventral and lateral marginal zone tissue from blastula- and gastrula-stage embryos can be dorsalized to the extent of muscle, but rarely to the extent of notochord, when recombined with (Slack and Forman 1980; Dale and Slack 1987; Stewart and Gerhart 1990, 1991) or implanted into (Smith and Slack 1983) the dorsal marginal zone. Because endogenous Xwnt-8 is normally expressed in ventral and lateral marginal zone cells during the period over which the organizer functions, it is feasible that $X w n t-8$ provides a signal that attenuates the response of these cells to dorsalizing signals in vivo. Furthermore, in an in vitro assay that is suggested to reflect mesoderm induction in vivo, activin can respecify the fate of dorsal ectoderm to form notochord and forebrain, whereas ventral ectoderm can only be induced to form tissues of more ventral and posterior character, including muscle and hindbrain (Sokol and Melton 1991; Bolce et al. 1992). We speculate that this differential response of explants to signals initiated by activin may be mediated by zygotically expressed $X w n t-8$, because activin is a potent inducer of Xwnt-8 expression in ventral, but not dorsal, animal cap ectoderm (Fig. 2) and because ectopic expression of Xwnt-8 in post-mid-blastula-stage dorsal ectoderm can prevent the activin-mediated induction of notochord. Finally, embryological experiments have shown that ventral (that is, Xwnt-8-expressing) mesoderm, when recombined with dorsal mesoderm, is incapable of ventralizing the latter tissue (Smith and Slack 1983; Dale and Slack 1987). Although this might seem to argue against the possibility that endogenous $X w n t-8$ attenuates the response of cells to dorsalizing signals in vivo, it is plausible that the $X w n t-8$ signal cannot spread beyond, and thus will only affect, expressing cells. Consistent with this theory, studies in cultured cells (Bradley and Brown 1990; Papkoff and Schryver 1990) led to the conclusion that members of the Wnt family, although secreted, remain tightly adherent to producing cells.

The observation that ectopic expression of Xwnt-8 af- 
ter the mid-blastula stage promotes the differentiation of isolated animal caps as ventral mesoderm suggests a further role for $X w n t-8$ as an agent involved in the steps of ventral mesoderm differentiation that occur after the mid-blastula transition. We have shown previously, however, that ectopic expression of Xwnt-8 in cleavagestage embryos, by injection of synthetic mRNA, does not cause autonomous mesodermal differentiation in isolated blastula caps (Christian et al. 1992). These differences in experimental observations have several potential explanations, including the possibility that Xwnt-8 polypeptide from injected RNA does not persist in isolated blastula caps long enough to exert an effect or that the dorsalizing effect of $X w n t-8$ on ectodermal cells before the mid-blastula stage precludes the ventralizing effect of any ectopic $X w n t-8$ which persists beyond this time. In vivo, mesoderm induction begins several hours before the onset of zygotic gene expression (Jones and Woodland 1987), indicating that endogenous agents involved in the primary induction of mesoderm must be maternally derived. Therefore, endogenous $X w n t-8$ cannot be a primary mesoderm-inducing agent, because it is first expressed after the mid-blastula transition /Christian et al. 1991). Nevertheless, the data support a potential role for Xwnt-8 in directing marginal zone cells toward a pathway of differentiation as ventral mesoderm. Dissecting such a role may not be trivial, as a number of other zygotic gene products have been implicated in the later steps of ventral mesoderm formation, and the role of $X w n t-8$ in this process may require the cooperation of these or other proteins. Examples of zygotic factors that promote ventral mesoderm formation include bone morphogenetic protein-4, a relative of the TGF- $\beta$ family (Köster et al. 1991; Dale et al. 1992; Jones et al. 1992) as well as Xbra, the Xenopus homolog of mouse brachyury (Cunliffe and Smith 1992).

Interestingly, many of the same phenotypic defects induced by ectopic expression of Xwnt-8, either before or after the mid-blastula transition, can be attained by treating amphibian embryos with lithium chloride during a similar developmental time. Before the mid-blastula transition, exposure of embryos to lithium (Nieuwkoop 1970; Kao et al. 1986; Kao and Elinson 1988; Slack et al. 1988; Cooke et al. 1989; Kao and Elinson 1989l, or injection of Wnt-1 or Xwnt-8 mRNA /Smith and Harland 1991; Sokol et al. 1991; Christian et al. 1992), potentiates the response of ectoderm to mesoderm-inducing agents such that it differentiates into dorsal mesoderm with Spemann organizer activity. After the mid-blastula transition, exposure to lithium or Xwnt-8 has a markedly different effect on the body pattern, producing a loss of structures anterior to the hindbrain (Yamaguchi and Shinagawa 1989), causing a transformation of presumptive notochord into somite tissue (Lehmann 1937; Cohen 1938; Bäckström 1954) and inducing mesodermal differentiations in ectoderm (Masui 1961). As with Xwnt-8, the primary target in lithium-induced microcephaly has been shown to be the head mesoderm, rather than the neuroctoderm (Hall 1942). Although the molecular mechanism by which the Xwnt- 8 signal is trans- duced is unknown, the effects of lithium in Xenopus are believed to be mediated by an inhibition of the polyphosphoinositide cycle (Busa and Gimlich 1989; Maslanski et al. 1992). Our current results strengthen the possibility that some Wnts may utilize a similar signaling pathway.

That embryonic cells respond differently to Xwnt-8 when it is expressed by injection of RNA, which is translated during cleavage stages, than they do to Xwnt-8 expressed by injection of plasmid DNA, which is only transcribed after the mid-blastula stage, is not surprising. Throughout embryogenesis, the competence of cells to respond to the same signals is altered as a result of intrinsic changes in the responding tissue, or through interactions with neighboring tissues (Jacobsen and Sater 1988). This may allow differences between cells to amplify rapidly and may enable a limited number of signaling molecules and signal transduction pathways to determine a broad range of cell fates. Importantly, patterning defects produced by ectopic expression of Xwnt-8 after the mid blastula transition, when endogenous $X$ wnt- 8 transcripts are present, are more likely to contribute to an understanding of the normal role of this gene product than are defects produced by ectopic expression in cleavage-stage embryos.

\section{Building the morphogenetic gradient field of the Spemann organizer}

The Spemann organizer behaves as a morphogenetic gradient field in which a dorsalizing signal emitted from a small population of cells diminishes in strength with increasing distance from its source (for review, see Slack 1991). In vertebrates, unlike Drosophila, morphogen gradients are not generally established by simple diffusion of factors from a point source but are set up by sequential cell-cell interactions that ultimately lead to the graded distribution of signaling molecules within localized cell populations. A general model detailing the pathway by which the organizer is formed and functions is emerging. Generation of the Spemann organizer field begins before first cleavage, when rotation of the egg cortex establishes an inductive activity, the Nieuwkoop center, in a broad dorsal region of the embryo (Gerhart et al. 1991). This activity functions before the mid-blastula stage to modify the response of dorsal ectodermal cells to one or more broadly distributed mesoderm-inducing signals (Christian et al. 1992; for review, see Kimelman et al. 1992). While the identity of the agent responsible for Nieuwkoop center activity may include a Wht protein and/or noggin (Smith and Harland 1992), members of the FGF and activin families have been implicated as endogenous mesoderm-inducing signals. At the mid-blastula transition, the combination of the Nieuwkoop center activity and mesoderm-inducing agents triggers the expression of specific genes within dorsal marginal zone cells. These gene products may have two functions: generating the morphogens released by cells of the organizer and negatively regulating expression of the $X w n t-8$ gene. Shortly thereafter, $X w n t-8$ expression is induced in response to 
mesoderm-inducing agents in all marginal zone cells except those of the organizer field. Expression of the homeo box gene goosecoid is initiated shortly before the time that Xwnt- 8 transcripts are first detected, and these two genes are spatially expressed in nonoverlapping patterns in the marginal zone. These data, taken together with the observations that goosecoid can repress expression of $X w n t-8$ and can induce a secondary body axis when ectopically expressed in ventral cells, are consistent with the hypothesis that goosecoid may be the endogenous transcription factor that leads to the repression of $X w n t-8$ expression in organizer cells and that initiates the cascade of gene expression required to generate the organizer morphogens.

Our data suggest that during gastrulation, dorsoventral patterning of the mesoderm may require two signals: a dorsalizing signal that is emitted by cells of the Spemann organizer and that can act on nearby cells, and a second signal, generated at least in part by $X w n t-8$, in ventral and lateral marginal zone cells. This second signal initiates the post-mid-blastula stage steps of ventral mesodermal differentiation and attenuates the response of producing cells to dorsalizing signals from the organizer. According to this hypothesis, the dorsoventral character of the mesoderm is determined by the relative strength of the dorsalizing signal, in combination with the presence or absence of the Xwnt-8 signal. Organizer cells, which are exposed to the dorsalizing signal alone, assume an extreme dorsal mesodermal fate, differentiating as notochord and head mesoderm, whereas ventral marginal zone cells, which are exposed to the Xwnt-8 signal alone, assume an extreme ventral mesodermal fate, such as blood. Lateral marginal zone cells receive a dorsalizing signal, but their response is attenuated by the overlapping Xwnt-8 signal; thus, these cells differentiate with an intermediate fate as muscle and lateral plate. This type of model, in which mesoderm is initially specified as dorsal or ventral, and is then regionalized by dorsalizing signals from the organizer during gastrulation, has been proposed previously on the basis of the results of embryological studies (Smith and Slack 1983; Dale and Slack 1987a, for review, see Slack 1991). Our results extend this model by identifying $X w n t-8$ as a component of the pathway leading to ventral mesodermal differentiation. In addition, we suggest that the $X w n t-8$ signal may change the competence of lateral cells to respond to the dorsalizing signal, and this may help to establish the gradient properties of the organizer field. Consistent with this idea, Stewart and Gerhart (1990)/Gerhart et al. 1991) have shown that dorsoventral patterning of the mesoderm requires an interaction between the organizer and neighboring cell populations of the lateral marginal zone. Whether Xwnt-8 assigns a ventral fate to cells, with further pattern a direct result of the graded strength of the organizer signal, or whether Xwnt-8 directly contributes to establishing the gradient properties of this signal, our data suggest that dorsoventral patterning of the mesoderm requires the $X w n t-8$ signal as well as the Spemann organizer signal and possibly an interaction between these activities.

\section{Materials and methods \\ Embryo culture and manipulation}

Xenopus eggs were obtained and embryos were cultured as described by Moon and Christian (1989). All embryonic stages are according to Nieuwkoop and Faber (1967). UV irradiation of zygotes was performed as described by Christian et al. (1991). To determine dorsal-ventral polarity of 32-cell or blastula-stage embryos, the prospective dorsal midline was marked with $1 \%$ Nile blue at the 4-cell stage. At this time, prospective dorsal blastomeres are smaller and pigmented more lightly than their ventral counterparts (Nieuwkoop and Faber 1967). When control embryos were allowed to develop until the dorsal lip of the blastopore was visible, the Nile blue mark was within $15^{\circ}$ of the dorsal midline in $>90 \%$ of cases.

\section{Mesoderm induction assays}

Animal caps, consisting of the uppermost one-third or twothirds (by surface area) of the pigmented portion of the embryo were obtained at stage 7-8 and cultured as described by Christian et al. (1991). Recombinant human activin A, supplied by Genentech, was used at concentrations of $4-40 \mathrm{ng} / \mathrm{ml}$ as indicated in Results. Various mesodermal cell types were identified by morphology (Green et al. 1990) in histological sections of explants fixed at control stage 40 .

\section{Histology}

Explants or whole embryos were fixed for $1 \mathrm{hr}$ in $4 \%$ paraformaldehyde $/ 0.25 \%$ glutaraldehyde in phosphate-buffered saline (PBS) at pH 7.4 and washed overnight in PBS. Fixed tissue was embedded in paraffin, and $10-\mu \mathrm{m}$-thick sections were cut and stained with hematoxylin-eosin, or with eosin alone (Kelly et al. 1991).

Immunolabeling and in situ hybridization of probes to whole embryos

Whole-mount immunocytochemical analysis of Xenopus embryos with the monoclonal antisera Tor70 (Kushner 1984; Bolce et al. 1992) or 9E10 (Evan et al. 1985) was as described by Moon and Christian (1989). Whole-mount in situ hybridization of riboprobes to Xenopus embryos was performed as described by Harland (1991). Digoxigenin-labeled Xwnt-8 riboprobes were made by in vitro transcription of pXwnt-8 (Christian et al. 1991). Goosecoid riboprobes were made by in vitro transcription of a goosecoid cDNA that was amplified from gastrula stage cDNA by use of the polymerase chain reaction (PCR) and primers specific for the published sequence (Cho et al. 1991).

\section{RNA analysis}

RNA was extracted from embryos or explants and analyzed by Northern hybridization to ${ }^{32} \mathrm{P}$-labeled cDNA or cRNA probes as described by Christian et al. (1991).

\section{Plasmid construction and microinjection}

The construct CSKA-CAT, generated from a cytoskeletal actin promoter from $\mathrm{H}$. Woodland (University of Warwick, England), was a gift of R. Harland (University of California, Berkeley). To generate CSKA-X8, the CAT-coding sequences were removed from CSKA-CAT by digestion with BamHI to generate CSKApT. A partial-length Xwnt-8 cDNA, extending from the 5' Ncil site to the $3^{\prime}$ end of pXwnt-8 (Christian et al. 1991), which 
includes the full coding region, was subcloned into CSKApT in a sense orientation. The cDNA encoding $X w n t-8^{\text {myc }}$ was generated using PCR as described by Vallette et al. (1989). A $5^{\prime}$ portion of pXwnt- 8 was amplified in a reaction primed with the SP6 promoter primer (Promega) and a synthetic oligonucleotide, which includes sequence complimentary to that encoding amino acids $334-339$ of Xwnt-8, followed by 30 nucleotides complementary to sequence encoding the 10-amino-acid epitope of human c-myc (EQKLISEEDL; Evan et al. 1985) and a recognition site for XhoI. The remaining $3^{\prime}$ portion of pXwnt-8 was amplified using a primer that includes the recognition site for XhoI followed by sequence encoding amino acids 340-346 of $X w n t-8$, as well as a second primer complimentary to vector sequence found downstream of pXwnt-8. The product of the first reaction was digested with $\mathrm{NcoI}$ and $\mathrm{XhoI}$, and the second reaction products were digested with $X$ hoI and BamHI. The resulting restriction fragments were gel purified and ligated together with the fragment of NcoI/BamHI-cut CSKA-X8, which includes all of the vector sequences as well as some of the $5^{\prime}$ $X w n t-8$-coding region. The result is a $36-\mathrm{bp}$ in-frame insertion such that $X w n t-8^{\text {myc }}$ contains 12 extra amino acids spliced between residues 339 and 340 of Xwnt-8. Approximately $100 \mathrm{pg}$ of supercoiled DNA was injected per blastomere in a volume of $1 \mathrm{nl}$.

\section{In vitro transcription and microinjection of synthetic RNA}

Capped synthetic RNA was generated by in vitro transcription of p286 (Wnt-1; McMahon and Moon 1989) or pgsc (goosecoid; Cho et al. 1991). Approximately $500 \mathrm{pg}$ of Wnt-1 or goosecoid RNA was injected into the marginal zone of two ventral blastomeres at the four-cell stage as described (Moon and Christian 1989).

\section{Acknowledgments}

We thank M. Marks for help in preparing the constructs, G. Mather at Genentech for the activin, K. Cho for the goosecoid cDNA used for injections, R. Harland for pCSKA CAT and Tor70 antiserum, and C. Holt for the 9E10-producing cell line. We are indebted to $H$. Steinbesser and E. DeRobertis for sharing results with us before publication. The helpful comments of $R$. Stewart, L. McGrew, A. Demarais, and D. Kimelman are greatly appreciated. This work was supported by U.S. Public Health Service grants RO1 HD27525 and KO4 AR 1837 to R.T.M.

The publication costs of this article were defrayed in part by payment of page charges. This article must therefore be hereby marked "advertisement" in accordance with 18 USC section 1734 solely to indicate this fact.

\section{References}

Adelmann, H.B. 1934. A study of cyclopia in Amblystoma punctatum with special reference to the mesoderm. I. Exp. Zool. 67: 217-227.

Amaya, E., T.J. Musci, and M.W. Kirschner. 1991. Expression of a dominant negative mutant of the FGF receptor disrupts mesoderm formation in Xenopus embryos. Cell 66: 257270.

Asashima, M., H. Nakano, K. Shimada, K. Kinoshita, K. Ishii, H. Shibai, and N. Ueno. 1990. Mesodermal induction in early amphibian embryos by activin A (erthythroid differentiation factor). Roux's Arch. Dev. Biol. 198: 330-335.

Asashima, M., H. Nakano, H. Uchiyama, H. Sugino, T. Naka- mura, Y. Eto, D. Eijma, S.-I. Nishimatsu, N. Ueno, and K. Kinoshita. 1991. Presence of activin (erythroid differentiation factor) in unfertilized eggs and blastula of Xenopus laevis. Proc. Natl. Acad. Sci. 88: 6511-6514.

Bäckström, S. 1954. Morphogenetic effects of lithium on the embryonic development of Xenopus. Arkiv. Zool. 27: 527536.

Blumberg, B., C.V.E. Wright, E.M. De Robertis, and K.W.Y. Cho. 1991. Organizer-specific genes in Xenopus laevis embryos. Science 253: 194-196.

Bolce, M.E., A. Hemmati-Brivanlou, P.D. Kushner, and R.M. Harland. 1992. Ventral ectoderm of Xenopus forms neural tissue, including hindbrain, in response to activin. Development 115: 681-688.

Bradley, R.S. and A.M.C. Brown. 1990. The proto-oncogene int-l encodes a secreted protein associated with the extracellular matrix. EMBO I. 9: 1569-1575.

Busa, W.B. and R.L. Gimlich. 1989. Lithium induced teratogenesis in frog embryos prevented by a polyphosphoinositide cycle intermediate or a diacylglycerol analog. Dev. Biol. 132: 315-324.

Chakrabarti, A., G. Matthews, A. Colman, and L. Dale. 1992. Secretory and inductive properties of Drosophila wingless protein in Xenopus oocytes and embryos. Development 115: 355-369.

Cho, K.W.Y., B. Blumberg, H. Steinbesser, and E.M. De Robertis. 1991. Molecular nature of Spemann's organizer: the role of the Xenopus homeobox gene goosecoid. Cell 67: 11111120 .

Christian, J.L., J.A. McMahon, A.P. McMahon, and R.T. Moon. 1991. Xwnt-8, a Xenopus Wnt-1/int-1-related gene responsive to mesoderm inducing factors, may play a role in ventral mesodermal patterning during embryogenesis. Development 111: 1045-1056.

Christian, J.L., D.J. Olson, and R.T. Moon. 1992. Xwnt-8 modifies the character of mesoderm induced by bFGF in isolated Xenopus ectoderm. EMBO J. 11: 33-41.

Clarke, J.D.W., N. Holder, S.R. Soffe, and J. Storm-Mathisen. 1991. Neuroanatomical and functional analysis of neural tube formation in notochordless Xenopus embryos; laterality of the ventral spinal cord is lost. Development 112: 499516.

Cohen, A. 1938. Myotome fusion in the embryo of Amblystoma punctatum after treatment with lithium and other agents. $J$. Exp. Zool. 79: 461 .

Cooke, J., K. Symes, and E.J. Smith. 1989. Potentiation by the lithium ion of morphogenetic responses to a Xenopus inducing factor. Development 105: 549-558.

Cunliffe, V. and J.C. Smith. 1992. Ectopic mesoderm formation in Xenopus embryos caused by widespead expression of a Brachyury homologue. Nature 358: 427-430.

Dale, L. and J.M. Slack. 1987a. Fate map for the 32-cell stage of Xenopus laevis. Development 99: 527-551.

- 1987b. Regional specification within the mesoderm of early embryos of Xenopus laevis. Development 100: 279295.

Dale, L., G. Howes, B.M.J. Price, and J.C. Smith. 1992. Bone morphogenetic protein 4: A ventralizing factor in early $\mathrm{Xe}$ nopus development. Development 115: 573-585.

Dirksen, M.L. and M. Jamrich. 1992. A novel, activin-inducible, blastopore lip-specific gene of Xenopus laevis contains a fork head DNA-binding domain. Genes \& Dev. 6: 599-608.

Evan, G.I., G.K. Lewis, G. Ramsey, and J.M. Bishop. 1985. Isolation of a monoclonal antibody specific for human c-myc proto-oncogene product. Mol. Cell. Biol. 5: 3610-3616.

Gallagher, B.C., A.M. Hainski, and S.A. Moody. 1991. Autono- 
mous differentiation of dorsal axial structures from an animal cap cleavage stage blastomere in Xenopus. Development 112: 1103-1114.

Gerhart, J.C., M. Danilchick, T. Doniach, S. Roberts, B. Rowning, and R. Stewart. 1989. Cortical rotation of the Xenopus egg: Consequences for the anteroposterior pattern of embryonic dorsal development. Development (Suppl.) 107: 37-51.

Gerhart, J.C., R. Stewart, and T. Doniach. 1991. Organizing the Xenopus organizer. In Gastrulation: Movements, patterns, and molecules (ed. R. Keller, W. Clark, Jr., and F. Griffin), pp. 55-77. Plenum Press, New York.

Gimlich, R.L. 1986. Acquisition of developmental autonomy in the equatorial region of the Xenopus embryo. Dev. Biol. 115: 340-352.

Gimlich, R.L. and J. Cooke. 1983. Cell lineage and the induction of second nervous systems in amphibian development. $\mathrm{Na}$ ture 306: 471-473.

Gimlich, R.L. and J.C. Gerhart. 1984. Early cellular interactions promote embryonic axis formation in Xenopus laevis. Dev. Biol. 104: 117-130.

Green, J.B.A., G. Howes, K. Symes, J. Cooke, and J.C. Smith. 1990. The biological effects of XTC-MIF: Quantative comparison with Xenopus bFGF. Development 108: 173-183.

Green, J.B.A., H.V. New, and J.C. Smith. 1992. Responses of embryonic Xenopus cells to activin and FGF are separated by multiple dose thresholds and correspond to distinct axes of the mesoderm. Cell 1: 1-20.

Hall, T.S. 1942. The mode of action of lithium salts in amphibian development. I. Exp. Zool. 89: 1-35.

Harland, R.M. 1991. In situ hybridization: An improved whole mount method for Xenopus embryos. Methods Cell. Biol. 36: 685-695.

Harland, R. and L. Misher. 1988. Stability of RNA in developing Xenopus embryos and identification of a destabilizing sequence in TFIIIA messenger RNA. Development 102: 837852.

Holtfreter, J. and V. Hamburger. 1955. Amphibians. In Analysis of development, (eds. B.H. Willier, P. Weiss, and V. Hamburger) W.B. Saunders Co., Philadelphia PA/London, England.

Jacobsen, A.G. and A.K. Sater. 1988. Features of embryonic induction. Development 104: 341-359.

Jones, C.M., K.M. Lyons, P.M. Lapan, C.V.E. Wright, and B.L.M. Hogan. 1992. DVR-4 (bone morphogenetic protein-4) as a posterior-ventralizing factor in Xenopus mesoderm induction. Development 115: 639-647.

Jones, E.A. and H.R. Woodland. 1987. The development of animal cell cap cells in Xenopus: A measure of the start of animal cap competence to form mesoderm. Development 101: 557-563.

Kageura, H. 1990. Spatial distribution of the capacity to initiate a secondary embryo in the 32-cell embryo of Xenopus laevis. Dev. Biol. 142: 432-438.

Kao, K.R. and R.P. Elinson. 1988. The entire mesodermal mantle behaves as Spemann's organizer in dorsoanterior enhanced Xenopus laevis embryos. Dev. Biol. 127: 64-77.

- 1989. Dorsalization of mesoderm induction by lithium. Dev. Biol. 132: 81-90.

Kao, K.R., Y. Masui, and R.P. Elinson. 1986. Lithium-induced respecification of pattern in Xenopus laevis embryos. Nature 322: 371-373.

Keller, R.E. 1976. Vital dye mapping of the gastrula and neurula of Xenopus laevis. Dev. Biol. 51: 118-137.

Kelly, G.M., D.W. Eib, and R.T. Moon. 1991. Histological preparation of Xenopus laevis oocytes and embryos. Methods Cell. Biol. 36: 389-417.
Kimelman, D., J.A. Abraham, T. Haaparanta, T.M. Palisi, and M.W. Kirschner. 1988. The presence of fibroblast growth factor in the frog egg: Its role as a natural mesoderm inducer. Science 242: 1053-1056.

Kimelman, D., J.L. Christian, and R.T. Moon. 1992. Synergistic principles of development: Overlapping patterning systems in Xenopus mesoderm induction. Development 116: 1-9.

Köster, M., S. Plessow, J.H. Clement, A. Lorenz, H. Tiedemann and W. Knöchel. 1991. Bone morphogenetic protein-4 (BMP. 4), a member of the TGF- $\beta$ family, in early embryos of $X e$ nopus laevis: Analysis of mesoderm inducing activity. Mech. Dev. 33: 191-200.

Kushner, P.D. 1984. A library of monoclonal antibodies to Torpedo cholinergic synaptosomes. J. Neurochem. 43: 775-786.

Lehmann, F.E. 1937. Mesodermisierung des praesumptiven chordamaterials durch einwirkung von lithium chlorid auf die gastrula von Triton alpestris. Wilhelm Roux's Arch. Entwicklungsmech. Org. 136: 112-116.

Maslanski, J.A., L. Leshko, and W.B. Busa. 1992. Lithium-sensitive production of inositol phosphates during amphibian embryonic mesoderm induction. Science 256: 243-245.

Masui, Y. 1961. Mesodermal and endodermal differentiation of the presumptive ectoderm of Triturus gastrula through influence of lithium ion. Experimentia 17: 458-459.

McMahon, A.P. and R.T. Moon. 1989. Ectopic expression of the proto-oncogene int-1 in Xenopus embryos leads to duplication of the embryonic axis. Cell 58: 1075-1084.

Moon, R.T. and J.L. Christian. 1989. Microinjection and expression of synthetic mRNAs in Xenopus embryos. Technique 1: 76-89.

Nieuwkoop, P.D. 1969. The formation of the mesoderm in urodelean amphibians I. The induction by the endoderm. Wilhelm Roux's Arch. Ent. Org. 162: 341-373.

- 1970. The formation of the mesoderm in urodelean amphibians. III. The vegetalizing action of the $\mathrm{Li}$ ion. Wilhelm Roux's Arch. Ent. Org. 166: 105-123.

Nieuwkoop, P.D. and J. Faber. 1967. Normal table of Xenopus laevis. North Holland Publishing Co., Amsterdam, The Netherlands.

Nordermer, J., F. Meijlink, P. Verrijzer, F. Rijsewijk, and O. Destree. 1989. Isolation of the Xenopus homologue of int-1 (wingless) and expression during neurula stages of development. Nucleic Acids Res. 17: 11-18.

Papkoff, J. and B. Schryver. 1990. Secreted int-1 protein is associated with the cell surface. Mol. Cell. Biol. 10: 2723-2730.

Sharpe, C.R., A. Pluck, and J.B. Gurdon. 1989. X1F3, a Xenopus peripherin gene, requires an inductive signal for enhanced expression in anterior neural tissue. Development 107: 701714.

Slack, J.M.W. 1991. From egg to embryo. Cambridge University Press, Cambridge, England.

Slack, J.M.W. and D. Forman. 1980. An interaction between dorsal and ventral regions of the marginal zone in early amphibian embryos. I. Embryol. Exp. Morphol. 56: 283-299.

Slack, J.M.W., B.G. Darlington, J.K. Heath, and S.F. Godsave. 1987. Mesoderm induction in early Xenopus embryos by heparin-binding growth factors. Nature 326: 197-200.

Slack, J.M., H.V. Isaacs, and B.G. Darlington. 1988. Inductive effects of fibroblast growth factor and lithium ion on blastula ectoderm. Development 103: 581-90.

Smith, J.C. and J.M. Slack. 1983. Dorsalization and neural induction: Properties of the organizer in Xenopus laevis. I. Embryol. Exp. Morphol. 78: 299-317.

Smith, W.C. and R.M. Harland. 1991. Injected Xwnt-8 acts early in Xenopus embryos to promote formation of a vegetal dorsalizing center. Cell 67: 753-766. 
1992. Expression cloning of noggin, a new dorsalizing factor localized in the Spemann organizer in Xenopus embryos. Cell 70: 829-840.

Smith, J.C., B.M.J. Price, K. Van Nimmen, and D. Huylebroeck. 1990. Identification of a potent Xenopus mesoderm-inducing factor as a homologue of activin A. Nature 345: 729-731.

Sokol, S., J.L. Christian, R.T. Moon, and D.A. Melton. 1991. Injected wnt RNA induces a complete body axis in Xenopus embryos. Cell 67: 741-752.

Sokol, S. and D.A. Melton. 1991. Pre-existent pattern in Xenopus animal pole cells revealed by induction with activin. Nature 351: 409-411.

Spemann, H. and H. Mangold. 1924. Uber induction von embryonalagen durch implantation artfremder organis atoren. Wilhelm Roux's Arch. Entwicklungsmech. Org. 100: 599638.

Stewart, R.M. and J.C. Gerhart. 1991. Induction of notochordby the organizer in Xenopus. Wilhelm Roux's Arch. Dev. Biol. 199: 341-348.

1990. The anterior extent of development of the Xenopus embryonic axis depends on the quantity of organizer in the late blastula. Development 109: 363-372.

Taira, M., M. Jamrich, P.J. Good, and I.B. Dawid. 1992. The LIM domain-containing homeobox gene Xlim-1 is expressed specifically in the organizer region of Xenopus gastrula embryos. Genes \& Dev. 6: 356-366.

Thomsen, G., T. Woolf, M. Whitman, S. Sokol, J. Vaughan, W. Vale, and D.A. Melton. 1990. Activins are expressed early in Xenopus embryogenesis and can induce axial mesoderm and anterior structures. Cell 63: 485-493.

Vallette, F., E. Mege, A. Reiss, and M. Adesnik. 1989. Construction of mutant and chimeric genes using the polymerase chain reaction. Nucleic Acids Res. 17: 723-733.

van den Eijnden-van Raaij, A.J.M., E.J.J. van Zoelent, K. van Nimmen, C.H. Köster, G.T. Snoek, A.J. Durston, and D. Huylebroeck. 1990. Activin-like factor from a Xenopus cell line responsible for mesoderm induction. Nature 345: 732734.

Vize, P.D., D.A. Melton, A. Hemmati-Brivanlou, and R.M. Harland. 1991. Assays for gene function in developing embryos. Methods Cell. Biol. 36: 367-387.

Yamaguchi, Y. and A. Shinagawa. 1989. Marked alteration at mid-blastula transition in the effect of lithium on the larval body pattern of Xenopus laevis. Dev. Growth Differ. 31: 531-541.

Youn, B.W. and G.M. Malacinski. 1981. Axial structures development in ultraviolet-irradiated (notochord-defective) amphibian embryos. Dev. Biol. 83: 339-352.

Yuge, M., Y. Kobayakawa, M. Fujisue, and K. Yamana. 1990. A cytoplasmic determinant for dorsal axis formation in an early embryo of Xenopus laevis. Development 110: 10511056. 


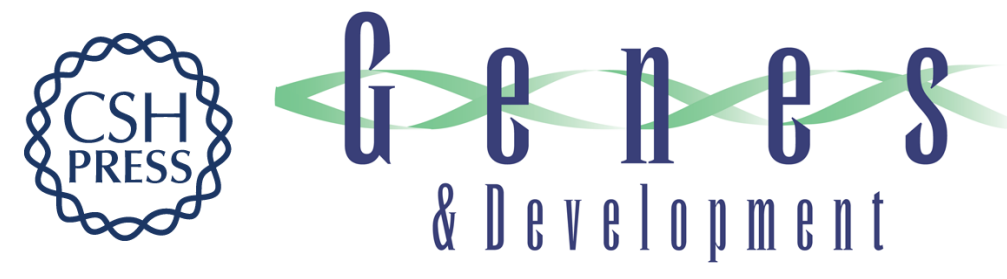

\section{Interactions between Xwnt-8 and Spemann organizer signaling pathways generate dorsoventral pattern in the embryonic mesoderm of Xenopus.}

$\mathrm{J}$ L Christian and R T Moon

Genes Dev. 1993, 7:

Access the most recent version at doi:10.1101/gad.7.1.13

References This article cites 75 articles, 28 of which can be accessed free at: http://genesdev.cshlp.org/content/7/1/13.full.html\#ref-list-1

License

Email Alerting Service

Receive free email alerts when new articles cite this article - sign up in the box at the top right corner of the article or click here.

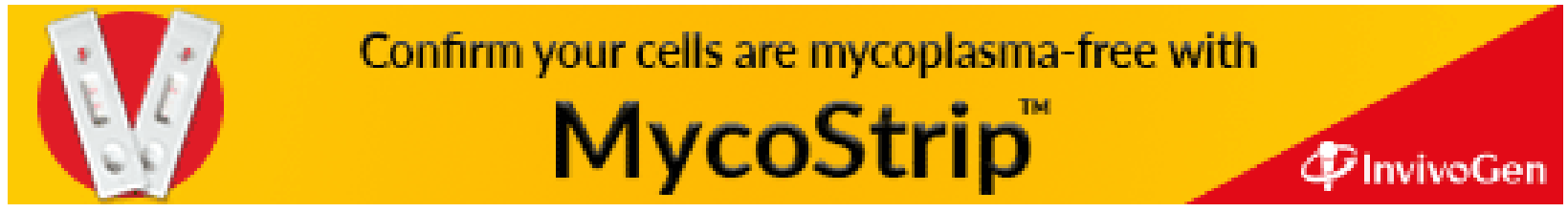

